\title{
Are You Updated?
}

\section{Karen C. Johnston, MD}

\section{ABPN}

Part I examination

Application deadline: February 1, 2004

Examination date: November 3, 2004

New subspecialties

1) Vascular neurology

a. Application deadline: August 1, 2004

b. Examination date: May 11, 2005

2) Psychosomatic medicine

a. Application deadline: August 1, 2004

b. Examination date: June 7, 2005

The full ABPN examination schedule is available at www.abpn.com

\section{ACGME}

Coming soon: a required resident survey—see http://www.acgme.org/

Coming soon: required resident case logs—see http://www.acgme. org/
AAN

Residency In-service Training Exam (RITE)

Examination dates: March 5, 6, 7, 2004

Resident scholarship to AAN meeting

Application deadline: February 15, 2004

Resident Fellow meeting at AAN date: April 25, 2003 


\title{
Neurology
}

\author{
Are You Updated? \\ Karen C. Johnston \\ Neurology 2004;62;E5 \\ DOI 10.1212/WNL.62.1.E5
}

This information is current as of January 12, 2004

\section{Updated Information \&}

Services

Permissions \& Licensing

Reprints including high resolution figures, can be found at: http://n.neurology.org/content/62/1/E5.full

Information about reproducing this article in parts (figures,tables) or in its entirety can be found online at:

http://www.neurology.org/about/about_the_journal\#permissions

Information about ordering reprints can be found online:

http://n.neurology.org/subscribers/advertise

Neurology ${ }^{\circledR}$ is the official journal of the American Academy of Neurology. Published continuously since 1951, it is now a weekly with 48 issues per year. Copyright. All rights reserved. Print ISSN: 0028-3878. Online ISSN: 1526-632X.

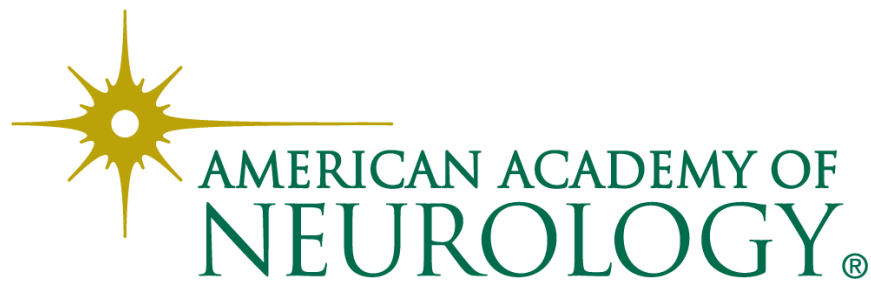

